\title{
FAKTOR-FAKTOR RESIKO PENYEBAB TERJADINYA STUNTING PADA BALITA USIA 23-59 BULAN
}

\section{RISK FACTORS CAUSES OF STUNTING IN TODDLERS AGED 23-59 MONTHS}

\author{
Linda Ika Puspita Ariati \\ Akademi Kebidanan Jember \\ Email: lindaikapuspita@gmail.com
}

\begin{abstract}
ABSTRAK
Stunting merupakan masalah kekurangan gizi kronis yang terjadi pada balita yang menyebabkan balita pendek dan terjadi retardasi pertumbuhan linear (RPL) yang selanjutnya dapat berdampak pada kesehatan secara lahiriah, namun meliputi kesehatan jiwa dan emosi, bahkan kecerdasan atau intelektualnya. Tujuan penelitian ini untuk mengetahui dan menganalisis hubungan faktor-faktor resiko penyebab terjadinya stunting pada balita usia 23-59 bulan di desa Panduman. Desain penelitian menggunakan cross sectional dengan jumlah sampel 111 balita yang didapat dengancara simple random sampling. Pengukuran data melalui pengukuran TB, wawancara Kuesioner, dan Foodrecall dan Analisis menggunakan Chi square. Hasil penelitian menunjukkan prevalensi stunting sebesar 32,5\% dan balita Normal 67,5\%. Analisis uji statistik menunjukkan adanya hubungan bermakna antara faktor prenatal (usia ibu saat hamil, status gizi ibu saat hamil), faktor pascanatal (ASI Eksklusif, riwayat imunisasi, penyakit infeksi), Karakteristik keluarga (pendidikan ibu, pekerjaan ayah dan status sosial ekonomi) dengan kejadian stunting.
\end{abstract}

Kata Kunci : Stunting, Faktor Penyebab, Balita Usia 23-59 Bulan.

\section{ABSTRACT}

Stunting is a chronic malnutrition problem that occurs in toddlers which causes short toddlers and linear growth retardation (RPL) which can subsequently affect health outwardly but includes mental and emotional health, even intelligence or intellect. The purpose of this study was to determine and analyze the relationship between risk factors that cause stunting in infants aged 23-59 months in Panduman village. The research design used cross-sectional with 111 samples of toddlers obtained by simple random sampling. Data measurement through TB measurement, questionnaire interview, and food recall and analysis using Chi-square. The results showed the prevalence of stunting was $32.5 \%$ and normal toddlers were $67.5 \%$. Statistical analysis showed a significant relationship between the factors of death (maternal age at pregnancy, maternal nutritional status during pregnancy), postnatal factors (Exclusive breastfeeding, immunization history, infectious diseases), family characteristics (maternal education, father's work, and socioeconomic status) with the incidence of stunting.

Keywords: Stunting, Causative factor, Toddlers Aged 23-59 Months.

\section{PENDAHULUAN}

Stunting merupakan masalah kekurangan gizi kronis pada balita yang menyebabkan gangguan pertumbuhan linear (RPL). Menurut WHO Child Growth Standart stunting didasarkan pada pada pengukuran panjang badan atau tinggi badan menggunakan batas $\mathrm{Z}$ score dengan indeks panjang badan dibanding umur $(\mathrm{PB} / \mathrm{U})$ atau tinggi badan dibanding umur $(\mathrm{TB} / \mathrm{U})<-2 \mathrm{SD}$. Keputusan Menteri Kesehatan No 
1995/MENKES/SK/XII/2010 tentang standart antropometri penilaian status gizi anak dibedakan menjadi 2 yaitu stunted (pendek / z score $<-2 \mathrm{SD}$ ) dan severely stunted (sangat pendek / z score $<-3$ SD (Kemenkes RI, 2016).

Indonesia menduduki peringkat ke lima dunia dan tertinggi di Asia Tenggara untuk jumlah anak dengan kondisi stunting. Berdasarkan hasil Riset Kesehatan Dasar (RISKESDAS) 2013 prevalensi stunting di Indonesia mencapai $37,2 \%$ yang artinya satu dari tiga balita mengalami stunting, dibandingkan dengan tahun sebelumnya angka stunting pada 2013 ini meningkat dari tahun 2010 (35,6\%) dan 2007 (36,8 $\%)$. Menurut WHO prevalensi stunting menjadi masalah kesehatan jika prevalensinya lebih dari $20 \%$ (Riskesdas,2013) dan prevalensi stunting ini masih jauh dari Indikator pencapaian gerakan seribu hari pertama kehidupan tahun 2025 yaitu menurunkan jumlah anak usia dibawah lima tahun yang stunting sebesar 9\%. Di Jawa Timur prevalensi stunting pada tahun 2016 sebesar 26,1 \% (Dinkes Jatim, 2016), sedangkan prevalensi di kabupaten Jember tahun 2014 sebesar 41,1\% Berdasarkan data dari dinas kesehatan Jember 2017 Kecamatan Jelbuk memiliki angka tertinggi kejadian stunting yaitu 39,3\% dengan jumlah kasus tertinggi stunting di desa Panduman sebanyak 102 kasus (Dinkes Jember,2017).

$$
\text { Stunting menjadi ancaman }
$$
terbesar bagi kualitas hidup manusia di masa mendatang karena dapat menghambat pertumbuhan fisik, hambatan pertumbuhan otak anak (kognitif), penurunan kualitas belajar hingga penurunan produktivitas di usia dewasa serta ancaman peningkatan penyakit tidak menular (Victoria et al, 2008). Stunting disebabkan oleh rendahnya asupan gizi dan penyakit berulang yang didasari oleh lingkungan yang tidak sehat (Kemenkes RI,2016), prevalensi stunting tinggi pada balita dengan rentang usia 0-5 tahun sebanyak (27\%) dengan puncaknya pada usia 2-5 tahun, hal ini sejalan dengan penelitian bi Bangladesh, India dan Pakistan dimana anak usia 24-59 tahun ditemukan dalam resiko lebih besar pertumbuhannya terhambat (Cunningham, 2006).

Gangguan pertumbuhan salah satunya stunting dapat dipengaruhi oleh faktor langsung dan faktor tidak langsung (Riskesdas,2013). Faktor langsung yang berhubungan dengan 
stunting diantaranya asupan nutrisi makanan dan status kesehatan. Kekurangan protein dan asupan energi berhubungan signifikan dengan kejadian stunting. Penelitian Stephenson et al (2010) di Kenya dan Nigeria menjelaskan bahwa asupan protein yang tidak adekuat pada anak usia 2-5 berhubungan dengan kejadian stunting7. kekurangan nutrisi pada usia ini akan berdampak pada pertumbuhan, perkembangan otak, mudah terserang penyakit dan infeksi. Gizi kurang terutama selama 1000 hari kehidupan pertama merupakan penyebab dasar gangguan pertumbuhan anak oleh karena itu, harus dicegah supaya tidak terjadi gangguan pertumbuhan, meskipun gangguan pertumbuhan fisik anak masih dapat diperbaiki di kemudian hari dengan peningkatan asupan gizi yang baik, namun tidak demikian dengan perkembangan kecerdasannya. Pemberian ASI eksklusif berkontribusi dalam kejadian stunting. Penelitian hidayah (2016) di Yogyakarta pemberian nutrisi ASI eksklusif berhubungan dengan kejadian stunting

Faktor tidak langsung yang berhubungan dengan stunting diantaranya Terkait dengan pelayanan kesehatan dan lingkungaan rumah tangga. status Imunisasi sebagai indikator kontak pelayanan kesehatan berdasarkan penelitian didapatkan anak yang tidak mendapatkan imunisasi rentan terjadi sakit dan memiliki hubungan signifikan dengan kejadian stunting. Pendidikan, pendapatan dan karakteristik keluarga berhubungan dengan kejadian stunting. Penelitian Samba et al 2008 tingkat pendidikan ibu dan ayah menjadi factor penyebab stunting di Indonesia. Pendidikan erat kaitannya dengan pekerjaan yang selanjutnya mempengaruhi status ekonomi keluarga.

Status ekonomi yang rendah menyebabkan ketidakterjangkauan dalam pemenuhan nutrisi sehari-hari yang pada akhirnya status ekonomi memiliki efek signifikan terhadap kejadian malnutrisi. Penelitian Oktarina 2014 di Sumatra menyebutkan bahwa Balita yang berasal dari keluarga dengan status ekonomi rendah memiliki resiko 2 kali mengalami stunting dibanding balita dari keluarga dengan status ekonomi tinggi (Stephenson et al, 2010)

Upaya yang telah dilakukan oleh pemerintah Indonesia untuk mengurangi masalah gizi pada bayi dan balita adalah pemberian ASI eksklusif dengan suplementasi zat gizi mikro pada anak - 
anak atau pemberian makanan yang diperkaya dengan vitamin dan mineral serta konseling kepada orang tua khususnya ibu, tentang praktek pemberian makanan, juga melalui program yang terintegrasi dengan bidang kesehatan (Kemenkes RI, 2016), Kejadian stunting bisa terus meningkat apabila faktor-faktor resiko yang telah dijelaskan tidak diperhatikan.

Tujuan penelitian ini adalah untuk mengetahui dan menganalisis hubungan faktor-faktor resiko penyebab terjadinya stunting pada balita usia 23-59 bulan di desa Panduman.

\section{METODE PENELITIAN}

Desain penelitian ini menggunakan cross secional. Dengan menggunakan kelompok kontrol. Populasi dalam penelitian ini adalah balita usia 23-59 bulan di wilayah kerja Puskesmas Jelbuk wilayah panduman sebanyak 352 balita, sampel dalam penelitian ini adalah balita usia 23-59 bulan sebanyak 111 balita dengan menggunakan tahnik simple random sampling. Pengumpulan data TB/U menggunakan mikrotoice, pengumpulan data faktor resiko kejadian stunting berupa kuesioner dan asupan energi dan protein menggunakan Food recall. Analisis yang digunakan dalam penelitian ini menggunakan uji Chi square.

\section{HASIL DAN PEMBAHASAN}

Penelitian ini dilakukan pada 111 balita usia 23-59 bulan yang memnuhi kriteria inklusi di desa Panduman wilayah kerja Puskesmas Jelbuk di Kabupaten Jember.

Dari hasil penelitian didapatkan kejadian stunting di desa panduman sebesar 32,4\% hasil variabel yang lain ditunjukan pada tabel sebagai berikut. 
Tabel 1. Faktor - faktor penyebab stunting dengan kejadian stunting pada Balita usia 23-59 bulan di desa Panduman

\begin{tabular}{|c|c|c|c|c|c|c|c|c|}
\hline \multirow[t]{2}{*}{ No } & \multirow[t]{2}{*}{ Karakteristik Responden } & \multicolumn{2}{|c|}{ Normal } & \multicolumn{2}{|c|}{ Stunting } & \multirow[t]{2}{*}{$\mathbf{N}$} & \multirow[t]{2}{*}{$\%$} & \multirow[t]{2}{*}{ p-value } \\
\hline & & $\mathbf{F}$ & $\%$ & $\mathbf{F}$ & $\%$ & & & \\
\hline \multirow[t]{3}{*}{1} & Usia Ibu saat hamil & & & & & & & 0.014 \\
\hline & Resiko & 57 & 75 & 19 & 25 & 76 & 100 & \\
\hline & Tidak beresiko & 18 & 51.4 & 17 & 48.6 & 35 & 100 & \\
\hline \multirow[t]{3}{*}{2} & Status Gizi Ibu saat Hamil & & & & & & & 0.000 \\
\hline & KEK & 5 & 14.3 & 30 & 85.7 & 35 & 100 & \\
\hline & Tidak KEK & 70 & 92.1 & 6 & 7.9 & 76 & 100 & \\
\hline \multirow[t]{3}{*}{3} & Usia kehamilan & & & & & & & 0.33 \\
\hline & Prematur & 6 & 54.5 & 5 & 45.5 & 11 & 100 & \\
\hline & Aterm & 69 & 69 & 31 & 31 & 100 & 100 & \\
\hline \multirow[t]{3}{*}{4} & Riwayat ASI Eksklusif & & & & & & & 0.000 \\
\hline & ASI Eks & 69 & 86.3 & 11 & 13.8 & 80 & 100 & \\
\hline & Tidak ASI Eks & 6 & 19.4 & 25 & 80.6 & 31 & 100 & \\
\hline \multirow[t]{3}{*}{5} & Asupan Energi & & & & & & & 0.065 \\
\hline & Baik $>100 \%$ AKG & 53 & 73.6 & 19 & 26.4 & 72 & 100 & \\
\hline & Kurang <100\% AKG & 22 & 56.4 & 17 & 43.6 & 39 & 100 & \\
\hline \multirow[t]{3}{*}{6} & Asupan Protein & & & & & & & 0.039 \\
\hline & Baik & 58 & 73.4 & 21 & 26.4 & 79 & 100 & \\
\hline & Kurang & 17 & 53.1 & 15 & 46.9 & 32 & 100 & \\
\hline \multirow[t]{3}{*}{7} & Status Penyakit Infeksi & & & & & & & 0.011 \\
\hline & Tidak Sakit & 72 & 79.1 & 19 & 20.9 & 91 & 100 & \\
\hline & Sakit & 3 & 15 & 17 & 85 & 20 & 100 & \\
\hline \multirow[t]{3}{*}{8} & Status Imunisasi & & & & & & & 0.011 \\
\hline & Lengkap & 75 & 69.4 & 33 & 30.6 & & 100 & \\
\hline & Tidak lengkap & 0 & 0 & 3 & 100 & & 100 & \\
\hline \multirow[t]{3}{*}{9} & Pendidikan Ibu & & & & & & & 0.048 \\
\hline & Rendah & 35 & 59.3 & 24 & 40.7 & 59 & 100 & \\
\hline & Menengah & 40 & 76.9 & 12 & 23.1 & 52 & 100 & \\
\hline \multirow[t]{3}{*}{10} & Pekerjaan Ibu & & & & & & & 0.797 \\
\hline & Bekerja & 61 & 67 & 30 & 33 & 91 & 100 & \\
\hline & Tidak Bekerja & 14 & 70 & 6 & 30 & 20 & 100 & \\
\hline \multirow[t]{3}{*}{11} & Pendidikan Ayah & & & & & & & 0.331 \\
\hline & Rendah & 54 & 65.1 & 29 & 34.9 & 83 & 100 & \\
\hline & Menengah & 21 & 75 & 7 & 25 & 28 & 100 & \\
\hline \multirow[t]{3}{*}{12} & Pekerjaan Ayah & & & & & & & 0.042 \\
\hline & Bekerja & 70 & 70.7 & 29 & 29.3 & 99 & 100 & \\
\hline & Tidak Bekerja & 5 & 41.7 & 7 & 58.3 & 12 & 100 & \\
\hline \multirow[t]{3}{*}{13} & Sosial Ekonomi & & & & & & & 0.000 \\
\hline & Tinggi & 65 & 84.4 & 12 & 15.6 & 77 & 100 & \\
\hline & Rendah & 10 & 29.4 & 24 & 70.6 & 34 & 100 & \\
\hline
\end{tabular}

Berdasarkan tabel 1 dapat diketahui bahwa faktor-faktor penyebab stunting yang memiliki hubungan bermakna dengan kejadian stunting di desa panduman adalah usia ibu saat hamil, status gizi ibu saat hamil, Riwayat ASI Eksklusif, Asupan protein, Status penyakit infeksi, Status imunisasi, Pendidikan ibu, Pekerjaan ayah dan Status ekonomi.

Usia ibu saat hamil yang tidak beresiko berkisar antara 20-35 tahun. Sedangkan usia ibu saat hamil yang beresiko $<20$ tahun dan $>35$ tahun. Usia reproduksi perempuan adalah 2035 tahun. Kehamilan dengan umur kehamilan 20-35 tahun merupakan 
masa aman karena kematangan organ reproduksi dan mental untuk menjalani kehamilan serta persalinan sudah siap Pada usia $<20$ tahun, organ-organ reproduksi belum berfungsi sempurna dan > 35 tahun terjadi penurunan reproduktif (Cunningham,2006). Usia diatas 35 tahun saat hamil memiliki resiko melahirkan anak stunting 2,74 kali dibanding ibu yang melahirkan pada usia 25-35 tahun (Y. Jiang et al, 2014).

Status gizi ibu saat hamil mempengaruhi pertumbuhan dan perkembangan janin janin yang dikandung. Ibu hamil Ibu yang mengalami kekurangan energi kronis (KEK) atau anemia selama kehamilan akan melahirkan bayi dengan berat badan lahir rendah (BBLR) (WHO, 2014). BBLR lahir rendah banyak dihubungkan dengan tinggi badan yang kurang atau stunting (Kemenkes RI, 2016). Oleh karena itu diperlukannya upaya pencegahan dengan menetapkan dan/atau memperkuat kebijakan untuk meningkatkan intervensi gizi ibu dan kesehatan mulai dari masa remaja (WHO, 2014). Ibu hamil merupakan salah satu kelompok rawan gizi perlu mendapatkan pelayanan kesehatan yang baik dan berkualitas agar ibu tersebut dapat menjalani kehamilannya dengan sehat (Kemenkes RI, 2012). Hasil penelitian ini sejalan dengan penelitian yang dilakukan oleh Sartono (2013) yang juga menunjukan hasil bahwa terdapat hubungan yang signifikan antara kekurangan energi kronis pada kehamilan (KEK) dengan kejadian stunting

Riwayat pemberian ASI Eksklusif sebagian besar balita di desa Panduman telah mendapatkan ASI eksklusif, hanya sebesar 19,6 \% yang tidak mendapatkan ASI eksklusif, namun dari balita dengan riwayat ASI tidak eksklusif tersebut sebagian besar jatuh dalam kondisi stunting. ASI merupakan nutrisi utama yang dibutuhkan oleh bayi karena merupakan sumber protein yang berkualitas dan mengandung zat-zat yang berguna untuk imunitas tubuh Roesli (2007). Kurangnya pemberian ASI dan pemberian MPASI dini dapat meningkatkan resiko terjadinya stunting pada masa awal kehidupan Gulkey (2007).

Asupan Protein sangat penting pada masa pertumbuhan, kekurang asupan protein akan menyebabkan terjadinya masalah gagal tumbuh (anak pendek/stunting) dengan berbagai 
dampak jangka panjang. Protein penting untuk fungsi normal dari semua sel dan proses metabolisme. Penelitian di Kenya dan Nigeria pada anak usia 2-5 tahun menunjukkan asupan protein yang tidak adekuat berhubungan dengan kejadian stunting (Stephenson. K. et al. 2010). anak yang hidup dengan asupan protein yang tidak memadai terjadi kelainan antropometri dan terjadi banyak efek klinis (Assis, et al. 2004)

$$
\text { Penyakit infeksi dapat }
$$
memperburuk keadaan gizi dan keadaan gizi yang kurang dapat mempermudah seseorang terkena penyakit infeksi yang akibatnya dapat menurunkan nafsu makan, adanya gangguan penyerapan dalam saluran pencernaan atau peningkatan kebutuhan zat gizi oleh adanya penyakit sehingga kebutuhan zat gizi tidak terpenuhi. Tando (2012) status kesehatan berupa frekuensi dan durasi sakit pada balita memberikan resiko kemungkinan terjadinya stunting pada anak. Terdapat hubungan timbal balik antara status gizi dan kejadian infeksi Balita yang mengalami status gizi buruk dapat meningkatkan terjadinya infeksi, sedangkan infeksi juga dapat mempengaruhi status gizi. Anak yang malnutrisi daya tahan tubuhnya rendah, sehingga akan mudah sakit dan akan menjadi semakin kurang gizi.

Imunisasi memiliki tujuan untuk mengurangi resiko morbiditas (kesakitan) dan mortalitas (komatian) anak akibat penyakit-penyakit yang dapat dicegah dengan imunisasi (Liliana, 2006). Program pemerintah untuk imunisasi yaitu pemberian imunisasi dasar lengkap, berdasarkan hasil penelitian didapatkan mayoritas $(97,2 \%)$ telah mendapatkan imunisasi dasar lengkap, dan hanya $8 \%$ yang tidak mendapatkan imunisasi dasar lengkap. Semua balita yang tidak mendapatkan imunisasi dasar lengkap mengalami stunting. Milman et al (2005) mengemukakan bahwa status imunisasi menjadi underlying factor dalam kejadian stunting pada anak usia $<5$ tahun.

Pendidikan ibu merupakan salah satu faktor yang penting dalam tumbuh kembang anak, karena dengan pendidikan yang baik, maka orang tua dapat menerima segala informasi dari luar terutama tentang tata cara pengasuhan anak yang baik, bagaimana menjaga kesehatan anaknya, pendidikannya, dan sebagainya (Soetjiningsih, 2006). Pendidikan ibu merupakan modal utama dalam 
penyusunan makan keluarga, pengasuhan dan perawatan anak (Suhardjo, 2003). ibu berpendidikan akan cenderung lebih baik menggunakan strategi demi kelangsungan hidup anaknya, Maka dari itu pendidikan pada ibu (seorang wanita) akan menjadi langkah berguna dalam pengurangan prevalensi mal nutrisi. Ibu yang memiliki pendidikan baik diperkirakan memiliki pengetahuan gizi yang baik. Ibu yang memiliki pengetahuan gizi yang baik diperkirakan akan tahu bagaimana mengolah makanan, mengatur menu makanan, serta menjaga mutu dan kebersihan makanan dengan baik (Astari,2005). Semakin tinggi tingkat pendidikan ibu maka semakin tinggi juga pengetahuan ibu tentang asupan makanan bagi balitanya dan semakin mudah ibu dalam mengolah informasi berkenaan dengan status gizi balitanya (Atmarita, 2004).

$$
\text { Peran ayah dalam dalam }
$$
mengasuh dan membesarkan anak begitu penting, sehingga tumbuh kembang anaknya optimal, untuk itu kematangan usia orang tua balita berperan dalam menjaga kesehatan anaknya termasuk pemenuhan makanan bergizi bagi balitanya. Pekerjaan ayah

,merupakan faktor utama penentu kualitas dan kuantitas kebutuhan pangan, pekerjaan berhubungan dengan pendapatan dalam keluarga yang mampu mencukupi kebutuhan semua keluarga dan berhubungan dengan status ekonomi keluarga. Di desa panduman didapatkan bahwa rata-rata pekerjaan ayah adalah sebagai buruh bangunan. Pekerjaan ayah memiliki hubungan bermakna dengan kejadian stunting berkaitan dengan pendapatan yang diterima (sosial ekonomi) terdapat kecenderungan yang sama dengan hasil penelitian ini, prevalensi stunting lebih tinggi pada keluarga dengan status ekonomi rendah. Keadaan ekonomi sosial yang baik dalam keluarga juga akan mempengaruhi kecukupan energi dan protein yang baik pada anak, hal ini terkait dengan kemampuan daya beli.

\section{SIMPULAN DAN SARAN}

Berdasarkan hasil penelitian menunjukkan faktor-faktor penyebab yang berhubungan dengan kejadian stunting di Desa Panduman adalah usia ibu saat hamil, status gizi ibu saat hamil, Riwayat ASI Eksklusif, Asupan protein, Status penyakit infeksi, Status imunisasi, Pendidikan ibu, Pekerjaan ayah dan Status ekonomi. 
Sehingga petugas kesehatan perlu memberi perhatian lebih pada faktor yang memiliki hubungan dengan kejadian stunting. Dan bagi puskesmas perlu meningkatkan upaya promotif dan preventif pada setiap faktor yang berhubungan dengan kejadian stunting.

\section{DAFTAR PUSTAKA}

Assis, et al. 2004. Childhood stunting in northeast Brazil: The Role of Schistosoma Monsoni Infection and Inadequate Dietary Intake. European Journal of Clinical Nutrition 58: 1022-1029.

Astari, LD, Nasoetion A \& Dwiriani CM. (2006). Hubungan Konsumsi ASI dan MP-ASI serta Kejadian Stunting Anak usia Di Kabupaten Bogor. Media Gizi dan Keluarga 30(1): 15- 23.

Atmarita (2005). Nutrition problem in Indonesia. The article for an Integrated international Seminar and workshop on lifestyle Related and disease. Gajah Mada University.

Cunningham, Gary F. 2006. Obstetri Williams (Suharyati Samba). Jakarta: EGC.

Dinas kesehatan Jember, Deseminasi Informasi Program Kesga dan Gizi tahun 2017, Dinkes, Jember.

Dinas provinsi Jawa Timur 2016. Profil Kesehatan Jawa Timur. Surabaya: Dinkes Provinsi Jawa Timur.
Kemenkes RI., 2016. Infodatin Pusat data dan informasi Kementrian kesehatan RI : Situasi Balita Pendek: pp. 1-2.

Kementerian Kesehatan RI. Riset Kesehatan Dasar 2013.

Milman A., Frongillo E.A., de Onis M. \& Hwang J.Y. Differential Improvement among Countries in Child Stunting is Associated with Long-term Development and Specific Interventions. The Journal of Nutrition. 2005; 135, 1415-1422.

Roesli, Utami. 2007. Mengenal ASI Eksklusif. Jakarta. Trubus Agriwidya.

Sartono. 2013. Hubungan Kurang Energi Kronis Ibu Hamil dengan Kejadian Stunting Pada Anak Usia 6-24 Bulan di Kota Yogyakarta. Tesis.Universitas Gajah Mada. Yogyakarta.

Soetjiningsih. Tumbuh Kembang Anak. Jakarta: Penerbit Buku Kedokteran EGC; 2000: 38-41, 211-7.

Stephenson. K. et al. 2010. "Consuming Cassava As Staple FOOD Places Children 2-5 Years Old at risk for in Adequate Protein Intake, an Observasional Study In Kenya and Nigeria" Nutrition Journal.

Suhardjo. 2003. Berbagai cara pendidikan gizi. Jakarta. Bumi Aksara.

Tando, N.M. 2012. Durasi dan frekuensi sakit balita dengan 
terjadinya stunting pada anak SD di kecamatan Malalayang Kota Manado. Jurnal Kesehatan, GIZIDO Vol. 4, No 1 Mei 2012. Hal 338-348.

Victora, C. G., Adair, L., Fall, C., Hallal, P. C., Martorell, R., Richter, L., \& Sachdev, H. S. (2008). Maternal and Child Undernutrition 2 Maternal and child undernutrition: consequences for adult health and human capital, 371, 340357.

WHO (2014). WHA Global Nutrion Targets 2025 : Stunting Policy Brief. WHO Press: Geneva.

Y. Jiang, X. Su, C. Wang, L. Zhang, X. Zhang, L. Wang and Y. Cui. ((2014). Prevalence and risk factors for stunting and severe stunting among children under three years old in mid-western rural areas of China. 